Jurnal Kesehatan

Volume 11, Nomor 2, Tahun 2020

ISSN 2086-7751 (Print), ISSN 2548-5695 (Online) http://ejurnal.poltekkes-tjk.ac.id/index.php/JK

\title{
Hubungan Nilai Trombosit dan Hematokrit dengan Kegagalan Arteriovenous Fistula pada Pasien Gagal Ginjal
}

\section{Relationship of Trombosit and Hematocrite Value with Arteriovenous Fistule Failure in Patients with Renal Failure}

\author{
Muhammad Satria ${ }^{1}$, Raflis Rustam ${ }^{2}$, Vendry Rivaldy ${ }^{3}$ \\ Bagian Ilmu Bedah RSUP. Dr. M. Djamil Padang; Fakultas Kedokteran, Universitas Andalas \\ Padang, Indonesia
}

\section{ARTICLE INFO}

\section{Article history}

Received date

07 August 2020

Revised date

19 August 2020

04 Sept 2020

Accepted date

17 Sept 2020

\section{Keywords:}

Arterovenous Fistula;

AVF failure;

Chronic kidney failure;

Hemodialysis.

\section{Kata kunci:}

Arterovenous Fistula;

Kegagalan AVF;

Gagal ginjal kronis;

Hemodialisis.

\begin{abstract}
ABSTRAK
Hemodialysis is a treatment for kidney failure that uses a machine to send the patient's blood through a filter. Arteriovenous fistulas (AVF) and arteriovenous grafts are vascular access that is designed for long-term use. In the world, the number of patients with endstage chronic kidney failure (CRF) which requires hemodialysis is increasing. However, almost $50 \%$ of arteriovenous fistulas can never be used for hemodialysis, and if they can be used, $25 \%$ will experience failure after 2 years. Many factors make the AVF failure, between the injury of the endothelial wall or the hypercoagulation. This study uses a cross-sectional retrospective design. Data is taken from the medical record status of patients with chronic kidney failure in RSUP Dr. M.Djamil Padang from January 2017 December 2019. Data were analyzed by Chi-square and Fisher test. From a sample of 33 people, patients obtained hematocrit values $<33 \%, 33-36 \%$, $>36 \%$ failure of AVF as many as 8,2 , and 4 people. While the platelet values $<150,000,150,000-400,000$ and 400,000 obtained AVF failures were 0.9 and 5 people. There was no relationship of platelet values with AVF failure in hemodialysis patients with $p$-value=0,323. There was a correlation between hematocrit values and AVF failure in hemodialysis patients with $\mathrm{p}$ value $=0,003$
\end{abstract}

Hemodialisis adalah pengobatan pada gagal ginjal yang menggunakan mesin untuk mengirimkan darah pasien melalui sebuah penyaring. Fistula arteriovenosa (AVF) dan cangkok arteriovenosa merupakan akses vaskuler yang didesain untuk penggunaan jangka panjang. Di dunia jumlah pasien gagal ginjal kronis (GGK) stadium akhir yang memerlukan hemodialisis semakin meningkat. Akan tetapi hampir 50\% fistula arteriovenosa tidak pernah dapat digunakan untuk hemodialisis, dan jika dapat digunakan, 25\% akan mengalami kegagalan setelah 2 tahun. Banyaknya faktor-faktor yang menyebabkan kegagalan AVF, diantaranya kerusakan dinding endotel atau adanya aliran darah yang lambat atau hiperkoagulasi. Penelitian ini menggunakan desain retrospective cross sectional. Data diambil dari status rekam medis pasien gagal ginjal kronis di RSUP Dr. M.Djamil Padang dari Januari 2017-Desember 2019. Data dianalisis dengan Chi-square dan Fisher test. Dari sampel 33 orang, didapatkan pasien nilai hematokrit $<33 \%, 33-36 \%,>36 \%$ kegagalan AVF sebanyak 8, 2, dan 4 orang. Sedangkan pada nilai trombosit $<150.000,150.000-400.000$ dan 400.000 didapatkan kegagalan AVF sebanyak 0,9 , dan 5 orang. Tidak terdapat hubungan nilai trombosit dengan kegagalan AVF pada pasien hemodialisis dengan $p$-value $=0,323$. Terdapat hubungan nilai hematokrit dengan kegagalan AVF pada pasien hemodialisis dengan $p$-value $=0,003$.

Corresponding Author:

Muhammad Satria

RSUP dr. M.Djamil Padang, Fakultas Kedokteran Universitas Andalas, Indonesia

Email: m.satria87@gmail.com 


\section{PENDAHULUAN}

Hemodialisis adalah pengobatan pada gagal ginjal yang menggunakan mesin untuk mengirimkan darah pasien melalui sebuah penyaring, yang disebut dializer, yang berada di luar tubuh. Jumlah dan tekanan darah yang mengalir ke dializer, harus memadai sehingga perlu suatu akses khusus. Akses khusus ini umumnya merupakan vena lengan yang sudah dibuatkan fistula dengan arteri radialis atau ulnaris. Fistula arteriovenosa dan cangkok arteriovenosa merupakan akses vaskuler yang didesain untuk penggunaan jangka panjang. Jenis yang lain yakni kateter vena sentral digunakan untuk penggunaan jangka pendek (NKDEP, 2014). Penilaian fungsi sistem vena dan arteri pada pemeriksaan fisik diperlukan untuk menyingkirkan adanya edema, skar paska pembedahan, pulsasi radius, ulna dan brakhial dan lingkaran vena superfisial.

Sebelum hemodialisis, setidaknya dibutuhkan waktu satu atau dua bulan untuk maturasi dari akses vaskuler (Santoro, et al., 2014). Ultrasonografi duplex merupakan standar emas dalam menentukan jenis dan lokasi dari akses vaskuler (Parisotto, et al., 2014).

Di dunia jumlah pasien gagal ginjal kronis (GGK) stadium akhir yang memerlukan hemodialisis semakin meningkat. Bila dibandingkan dengan laju pertumbuhan penduduk dunia yang hanya $1,1 \%$ per tahun, laju pertumbuhan penderita GGK stadium akhir sekitar 6-7\% per tahun. Masalah yang sering dihadapi pada pasien GGK stadium akhir adalah pemasangan dan pemeliharaan akses dialisis.

Jika dibandingkan dengan akses lainnya, penggunaan fistula arteriovenosa lebih disarankan sebagai akses hemodialisis, karena dapat digunakan untuk jangka panjang, jangka morbiditas dan mortalitas lebih rendah. Akan tetapi hampir $50 \%$ fistula arteriovenosa tidak pernah dapat digunakan untuk hemodialisis, dan jika dapat digunakan, 25\% akan mengalami kegagalan setelah 2 tahun (Schinstock, et al., 2011). Pada tahun 2013, angka kegagalan fistula arteriovenosa sebesar $35,9 \%$ dan rerata terjadi 135 hari setelah fistula arteriovenosa pertama kali digunakan (United States Renal Data System, 2015). Sekitar 30-61\% fistula arteriovenosa akan mengalami kegagalan untuk hemodialisis, baik karena kegagalan maturasi maupun trombosis (Macrae, et al., 2015).

Berdasarkan studi yang dilakukan oleh Gheith dan Kamal (dalam Sari, 2019), pada 200 pasien yang sedang menjalani terapi pengganti ginjal selama lebih dari 1 bulan melalui akses vaskuler permanen. Faktor risiko yang mungkin menyebabkan kegagalan akses vaskuler dievaluasi termasuk usia pertama mulai hemodialisis, jenis kelamin, diabetes mellitus, kadar baseline hormon paratiroid, dan penggunaan terapi antihipertensi dengan ACE Inhibitor atau ARB (Sari, dkk., 2019).

Sebuah studi meta-analisis mengenai hubungan antara pasien diabetes dengan gagalnya fistula arteriovenosa pada hemodialisis membuktikan hubungan yang secara statistik signifikan dan melaporkan tingginya angka kegagalan fistula arteriovenosa pada pasien diabetes dibandingkan dengan non-diabetes. (Yan Y, et al., 2018). Beberapa penelitian lain menunjukkan perubahan aterosklerotik pada arteri lengan bawah pada pasien diabetes muncul pada $60 \%$ pasien hemodialysis (Gołębiowski, et al., 2015).

Sari, dkk pada tahun 2019 mengevaluasi faktor risiko yang berperan dalam terjadinya kegagalan fistula arteriovenosa pada 78 orang pasien. Pada penelitian ini ditemukan bahwa usia lebih sama dari 50 tahun dan diabetes melitus merupakan faktor risiko murni yang mempengaruhi luaran kegagalan fistula arteriovenosa pada pasien dengan gagal ginal kronis stadium akhir dan bermakna terhadap waktu lebih cepat terjadinya kegagalan pada fistula arteriovenosa'

Martinez-Mier, et al. (2020), mengemukakan dalam studi retrospektif terhadap Arteriovenous fistula selama periode 6 tahun bahwa kadar albumin serum pra operasi dan prothrombin time kemungkinan merupakan faktor risiko yang berhubungan dengan ketidakberhasilan penggunaan Arteriovenous fistula. Sarioglu, et al., menemukan bahwa tingginya rasio trombositlimfosit mungkin mendukung temuan adanya stenosis dan trombosis Arteriovenous fistula (Sarioglu, et al., 2019). Lano G, et al. (2019), melakukan studi mengenai mean platelet volume (MPV) pada pasien hemodialisis dimana mereka menyimpulkan bahwa insiden disfungsi akses vaskuler tinggi pada pasien dengan kadar MPV yang tinggi.

Chang CJ, et al. (2005), mengamati bahwa infiltrasi oleh makrofag dan limfosit dalam lapisan vaskular dari AVF yang obstruksi menyebabkan peningkatan aktivitas inflamasi. Aterosklerosis dapat menyebabkan gangguan pada endotel pembuluh darah, memungkinkan akumulasi trombosit pada endotelium dan memulai pembekuan. Hal ini berpotensi mengalami degenerasi menjadi obstruksi pembuluh (Pearson JD, 1994). Ketika endotelium mengalami deteriorisasi, sel endotel 
memproduksi dan melepaskan berbagai zat, termasuk plasminogenaktivator inhibitor-1, faktor von Willebrand, tromboksan A2, fibrinogen, dan faktor jaringan yang dapat digunakan sebagai indikator derajat disrupsi endotel (Galley, et al., 2004).

Penelitian Chang CJ, et al. (2005) menunjukkan bahwa fistula arteriovenosa yang mengalami thrombosis memperlihatkan tanda peradangan yang nyata. Chang, et al., membandingkan aktivitas inflamasi segmen vena yang mengalami trombosis versus fistula arteriovenosa non-trombosis dengan memeriksa infiltrasi makrofag dan limfosit, dan ekspresi molekul terkait peradangan, termasuk molekul adhesi, intercellular adhesion molecule-1 (ICAM-1) dan vascular cell adhesion molecule-1 (VCAM-1), dan sitokin proinflamasi, interleukin-6 (IL-6) dan tumor necrosis factor- $\alpha$ (TNF- $\alpha)$ menggunakan metode imunohistokimia. Penelitian ini menunjukkan infiltrasi yang banyak dari makrofag dan jumlah limfosit yang kecil hingga sedang di dinding pembuluh darah fistula arteriovenosa yang mengalami trombosis disertai dengan peningkatan ekspresi VCAM-1 dan sitokin proinflamasi, IL-6 dan TNF-a. Temuan Ini menunjukkan aktivitas inflamasi terlibat di dinding pembuluh darah fistula arteriovenosa trombosis.

Makrofag dan limfosit dari kelompok trombosis berlimpah dan lebih besar daripada orang-orang dari kelompok non-trombosis (masing-masing $p$-value $<0,001$ dan $p$ value $=0,001$ ). Infiltrasi makrofag dan neovaskular berkorelasi erat. Ekspresi VCAM-1, IL-6, dan TNF-a secara signifikan lebih tinggi pada kelompok trombosis ( $p$-value $=0,031, p$ value $=0,010, p$-value $<0,001$, dan $p$-value $=1.000$, masing-masing) tetapi tidak ICAM-1. Ekspresi MMP-2 tidak berbeda pada kedua kelompok ( $p$ value $=0,344)$. Ekspresi diferensial MMP-9 oleh makrofag di dekat lumen vaskuler diamati pada sebagian besar spesimen yang trombosis (Chang CJ, et al., 2005).

Kaygin MA, et al. (2013), menilai bahwa evaluasi inflamasi sebelum membuat Arteriovenous fistula pada pasien HD sangat penting untuk meningkatkan keberhasilan Arteriovenous fistula. Berbagai faktor yang mempengaruhi patensi Arteriovenous fistula pada pasien penyakit ginjal kronis stadium akhir membuat penulis tertarik untuk meneliti lebih lanjut mengenai hubungan nilai trombosit dan hematokrit dengan kegagalan Arteriovenous fistula pada pasien gagal ginjal di RSUP Dr. M. Djamil Padang.
Sebelum hemodialisis, setidaknya dibutuhkan waktu satu atau dua bulan untuk maturasi dari akses vaskuler. Dalam menentukan tipe akses vaskuler, pendekatan teknik dan tindak lanjut yang benar untuk penanganan komplikasi memerlukan evaluasi klinik dan instrumen. Mencegah pengambilan darah atau infus intravena pada lengan atas, lengan bawah, dan menggunakan vena di tangan penting untuk tetap menjaga sistem vaskuler (Santoro, et al., 2014).

Pengumpulan riwayat medis, pemeriksaan fisik dan evaluasi instrumen termasuk dalam tahap preoperative (Parisotto, et al., 2014). Anamnesis mengenai riwayat penyakit jantung untuk menilai adanya perubahan curah jantung. Perubahan aliran darah, tekanan pulmonal dan curah jantung terutama ketika aliran darah pada fistula arteriovenosa lebih dari $2000 \mathrm{ml} /$ menit (Santoro, et al., 2014). Kateterisasi vena sentral dan/atau arteri sebelumnya harus telah diinvestigasi untuk risiko tinggi stenosis vena sentral dengan konsekuensi berkurangnya curah vena akses vaskuler pada masa yang akan datang. Selain itu penting untuk mengidentifikasi anggota tubuh yang dominan untuk mencegah keterbatasan kualitas hidup pasien (MartinezMier, et al., 2019).

Penilaian fungsi sistem vena dan arteri pada pemeriksaan fisik diperlukan untuk menyingkirkan adanya edema, skar paska pembedahan, pulsasi radius, ulna dan brakhial dan lingkaran vena superfisial. Tes Allen harus dilakukan untuk mengevaluasi adanya abnormalitas vaskularisasi arkus palmaris. (Santoro, et al., (2014).

Ultrasonografi duplex merupakan standar emas dalam menentukan jenis dan lokasi dari akses vaskuler. Pemeriksaan ini menilai diameter arteri dan vena, diameter vena $>2 \mathrm{~mm}$ dan diameter arteri $>1,6 \mathrm{~mm}$ yang dipertimbangkan secara adekuat. Hal ini merupakan faktor prediktif dalam menentukan maturasi fistula arteriovenosa (NKDEP, 2014).

Berdasarkan panduan the National Kidney Foundation (NKDEP, 2014), lokasi pembedahan fistula arteriovenosa pada hemodialisis yaitu (NKF-K/DOQI): lengan bawah (radio-sefalika atau fistula arteriovenosa distal), siku (brakhiosefalika atau fistula arteriovenosa proksimal), lengan (fistula arteriovenosa brakhial-basilika dengan transposisi atau fistula arteriovenosa proksimal). Pembuatan fistula arteriovenosa secara langsung pada pergelangan tangan dipertimbangkan sebagai standar emas untuk akses vaskuler. Hal ini disebabkan karena secara prosedur relatif mudah dikerjakan dan rendahnya kejadian komplikasi, nilai patensi jangka 
lamanya bagus dan tidak menghalangi kemungkinan untuk pembuatan akses di masa yang akan datang. Terdapat beberapa tipe berbeda anastomosis arteriovenosa yaitu: side-toend of the vein on the artery, latero-lateral, terminalized side-to-side, side-to-end of tha artery on vein, and end-to-end. Jenis yang paling sering adalah anastomosis of the vein side-to-side of the artery.

Nilai patensi untuk akses distal pada 1 tahun, dilaporkan bervariasi antara $56-79 \%$. Fistula arteriovenosa proksimal merupakan pilihan kedua. Jenis fistula arteriovenosa ini memiliki keuntungan karena menggunakan bahan autologous kaliber besar, yang memfasilitasi pembuatan akses dan kanulasi vena untuk penggunaan akses, serta angka patensi yang lebih tinggi dibandingkan dengan yang distal. Namun, kekurangan jenis ini adalah pada tingkat komplikasi yang lebih tinggi seperti steal syndrome dan perubahan arteri pada curah jantung (NKDEP, 2014).

Fistula arteriovenosa brakhio-basilika membutuhkan prosedur teknis tambahan, yaitu superfisialisasi vena basilika. Prosedur ini dapat dilakukan dalam dua tahap, dengan keuntungan dapat menangani vena yang sudah terarterialisasi dan oleh sebab itu menjadikannya lebih resisten, tetapi dengan kelemahan penggunaan akses yang lebih tertunda (Pearson JD, 1994).

Tingkat patensi satu tahun untuk akses proksimal dilaporkan dalam literatur bervariasi dari $70 \%$ hingga $84 \%$. Sebelum mulai menggunakan Arteriovenous fistula, diperlukan waktu untuk mendapatkan modifikasi struktural dinding vena yang terdiri dari "arterialisasi" sebagai akibat dari turbulensi aliran. Menurut pedoman NKF-K/DOQI 2006, akses dapat didefinisikan fungsional ketika aliran $>600 \mathrm{~mL} /$ menit, diameter vena minimum $0,6 \mathrm{~cm}$ dan kedalaman tidak melebihi $0,6 \mathrm{~cm}$, dan margin dapat diidentifikasi dengan jelas. Waktu yang dibutuhkan yakni berkisar dari 1 hingga 3 bulan dari pembuatan Arteriovenous fistula. Untuk mengevaluasi parameter tersebut di atas, diperlukan pemantauan klinis dan instrumen yang cermat (NKDEP, 2014).

Komplikasi yang paling sering terkait dengan Arteriovenous fistula adalah pematangan fistula arteriovenosa yang tidak mencukupi, stenosis, trombosis, infeksi, aneurisma, steal syndrome karena iskemia, dan aliran fistula arteriovenosa tingkat tinggi (Santoro, et al., 2014).

Kegagalan Arteriovenous fistula juga dapat dikaitkan dengan stenosis arteri vena. Komplikasi ini dapat dikoreksi dengan menggunakan prosedur endovaskular atau pembedahan, sehingga segmen stenotik yang pendek dapat dikoreksi dengan angioplasti transluminal perkutan, sementara surgical replacement adalah baku emas untuk segmen stenotik yang lebih luas (Santoro, et al., 2014).

\section{METODE}

Penelitian ini menggunakan metode desain retrospective cross sectional. Data diambil dari status rekam medis pasien gagal ginjal kronis di RSUP Dr. M.Djamil Padang dari Januari 2017-Desember 2019. Jumlah sampel yang diambil dari rekam medis sebanyak 33 sampel dan ini telah dimasukkan kedalam kriteria inklusi dan ekslusi. Dari kriteria inklusi yakni pasien gagal ginjal kronis yang akan menjalankan prosedur AVF, data laboratorium lengkap hal ini yang diambil data nilai trombosit dan nilai hematokrit pre op. untuk kriteria ekslusi peneliti menyingkirkan data pasien yang sudah meninggal, pasien yang tidak kontrol lagi ke poli bedah vaskuler, kemudian data laboratorium yang tidak lengkap. Selanjutnya data dianalisis dengan Chi-square jika data memenuhi syarat dan Fisher test, jika data tidak memenuhi syarat.

Penelitian ini telah mendapatkan Keterangan Lolos Kaji Etik (Ethical Approval) dengan Nomor 197/KEPK/2020 dari Komite Etik Penelitian Kesehatan RSUP Dr. M. Djamil Padang.

\section{HASIL}

\section{Tabel 1. Karakteristik Responden}

\begin{tabular}{llrr}
\hline Variabel & \multicolumn{1}{c}{ Kategori } & \multicolumn{1}{c}{ f } & \% \\
\hline Jenis & Perempuan & 8 & 24,2 \\
Kelamin & Laki-laki & 25 & 75,8 \\
\hline \multirow{2}{*}{ Usia } & $<45$ tahun & 8 & 24,2 \\
& $45-60$ tahun & 15 & 45,5 \\
& $>60$ tahun & 10 & 30,3 \\
\hline \multirow{2}{*}{ Hipertensi } & Ya & 21 & 63,6 \\
& Tidak & 12 & 36,4 \\
\hline \multirow{2}{*}{ DM } & Ya & 23 & 69,7 \\
& Tidak & 10 & 30,3 \\
\hline \multirow{2}{*}{ Jantung } & Ya & 5 & 15,2 \\
& Tidak & 28 & 84,8 \\
\hline \multirow{2}{*}{ Tipe AVF } & Radiocephalica & 20 & 60,6 \\
& Braciocephalica & 13 & 39,4 \\
\hline \multirow{2}{*}{ Kadar } & $<150.000$ & 1 & 3,0 \\
Trombosit & $150.000-400.000$ & 24 & 72,7 \\
& $>400.000$ & 8 & 24,3 \\
\hline \multirow{2}{*}{ Hematokrit } & $<33$ & 27 & 81,8 \\
& $33-36$ & 2 & 6,1 \\
& $>36$ & 4 & 12, \\
\hline
\end{tabular}


Hasil penelitian diperoleh dengan pengamatan hasil rekam medis dengan mengumpulkan data, jenis kelamin, usia, komorbid, jenis tindakan AVF, nilai trombosit, hematokrit, apakah berhasil dilakukan hemodialisis atau tidak. Sebanyak 33 pasien yang masuk dalam kriteria inklusi, dengan pembagian data yang berhasil dilakukan hemodialisis dengan yang gagal hemodialisis. Berikut data karakteristik pasien ditampilkan pada table berikut.

Peneliti mendapatkan gambaran dari karakteristik pasien. Disini didapatkan jenis kelamin laki-laki merupakan pasien terbanyak dari pasien gagal ginjal yaitu sebanyak 25 orang (78,5\%), dan usia terbanyak berkisar antara 4560 tahun. Selanjutnya penyakit diabetes melitus merupakan komorbid terbanyak pada pasien gagal ginjal RSUP Dr.M.Djamil Padang.

Tabel 2. Hubungan Kadar Hematokrit pada Pasien Gagal Ginjal Kronis dengan Kegagalan AVF pada Pasien Hemodialisis

\begin{tabular}{|c|c|c|c|c|c|c|c|}
\hline \multirow{2}{*}{$\begin{array}{l}\text { Hema- } \\
\text { tokrit }\end{array}$} & \multicolumn{2}{|c|}{ Berhasil } & \multicolumn{2}{|c|}{$\begin{array}{c}\text { Tidak } \\
\text { berhasil }\end{array}$} & \multicolumn{2}{|c|}{ Total } & \multirow{2}{*}{$\begin{array}{c}p- \\
\text { value }\end{array}$} \\
\hline & f & $\%$ & f & $\%$ & f & $\%$ & \\
\hline$<33$ & 19 & 70,4 & 8 & 29,6 & 27 & 100 & \\
\hline $33-36$ & 0 & 0 & 2 & 100 & 2 & 100 & 0,003 \\
\hline$>36$ & 0 & 0 & 4 & 100 & 4 & 100 & \\
\hline
\end{tabular}

Dari tabel 2 diperoleh hasil bahwa sebagian besar pasein yang memiliki nilai hematokrit dibawah 33 Tindakan AVF-nya berhasil $(70,4 \%)$ hanya sebagian kecil pasien yang nilai hematokritnya di bawah 33 mengalami kegagalan AVF, sedangkan seluruh pasein dengan nilai hematokrit diantara 33-36\% semuanya mengalami kegagalan AVF (100\%). Berdasarkan hasil uji statistik dengan analisis chi square diperoleh nilai p-value sebesar 0,003, artinya terdapat hubungan yang signifikan antara kadar hematokrit dengan kegagalan AVF pada pasien hemodialisa.

Tabel 3. Hubungan Kadar Trombosit pada Pasien Gagal Ginjal Kronis dengan Kegagalan AVF pada Pasien Hemodialisis

\begin{tabular}{|c|c|c|c|c|c|c|c|}
\hline \multirow{2}{*}{$\begin{array}{c}\text { Kadar } \\
\text { trombosit }\end{array}$} & \multicolumn{2}{|c|}{ Berhasil } & \multicolumn{2}{|c|}{$\begin{array}{c}\text { Tidak } \\
\text { berhasil }\end{array}$} & \multicolumn{2}{|c|}{ Total } & \multirow{2}{*}{$\begin{array}{c}p- \\
\text { value }\end{array}$} \\
\hline & $\mathbf{f}$ & $\%$ & $\mathbf{f}$ & $\%$ & f & $\%$ & \\
\hline$<150.000$ & 1 & 100 & 0 & 0 & 1 & 100 & \\
\hline $\begin{array}{l}150.000- \\
400.000\end{array}$ & 15 & 62,5 & 9 & 37,5 & 24 & 100 & 0,323 \\
\hline$>400.000$ & 3 & 37,5 & 5 & 62,5 & 8 & 100 & \\
\hline
\end{tabular}

Berdasarkan tabel 3 diperoleh hasil bahwa lebih dari separuh pasien $(62,5 \%)$ dengan nilai trombosit pada rentang 150.000 dampai dengan 400.000 berhasil dilakukan tindakan AVF, seluruh pasien (100\%) dengan kadar trombosit di bawah 150.000 juga menunjukan keberhasilan pada tindakan AVF, namun lebih dari separuh pasien $(62,5 \%)$ yang kadar trombositnya di atas 400.000 tidak berhasil dilakukan AVF. Berdasarakan uji statistik dengan menggunakan analisis Chi Square diperoleh nilai $p$-value sebesar 0,323 , artinya tidak ada hubungan yang signifikan antara kadar trombosit dengan kegagalan AVF pada pasien Hemodialisis.

\section{PEMBAHASAN}

Sebanyak 33 pasien yang masuk dalam kriteria inklusi, dengan pembagian data yang berhasil dilakukan hemodialisis dengan yang gagal hemodialisis. Data diolah dengan menggunakan IBM SPSS versi 22. Data kategorik dengan nilai asli dan sebagai persentase yang dilaporkan sebagai mean \pm SD dan dibandingkan dengan uji $\mathrm{x}^{2}$ bila syarat uji $\mathrm{x}^{2}$ terpenuhi dan uji Fisher bila syarat uji chi square tidak terpenuhi.

Hasil penelitian ini menunjukkan bahwa laki-laki lebih banyak menjalani operasi AVF sebanyak 25 orang $(754,8 \%)$ sedangkan perempuan sebnayak 8 orang $(24,2 \%)$. Sari NM, et al (2019), melaporkan pasien laki-laki yang menjalani operasi cimino sebanyak 52 orang $(66,7 \%)$.

Usia terbanyak yang menjalani operasi AVF pada penderita GGK terbanyak adalah antara 45-60 tahun, sebanyak 15 orang $(45,5 \%)$, diikuti urutan kedua terbanyak $>60$ tahun sebanayk 10 orang $(30,3 \%)$ dan $<45$ tahun sebanyak 8 orang $(24,2 \%)$. Pada penelitian Sari, dkk (2019), usia terbanyak yaitu diatas 50 tahun $(48,7 \%)$ dan usia diatas 50 tahun mengalami kegagalan AVF lebih cepat disbanding usia dibawah 50 tahun. Kaygin, et al., (2013), menemukan usia rata-rata kegagalan AVF $56,36 \pm 15,6$ tahun.

Diabtes mellitus, hipertensi dan jantung merupakan komorbid terbanyak ditemukan pada pasien GGK. Pada penelitian ini diabetes mellitus merupakan penyebab kegagalan AVF pada pasien GGK yang akan menjalani hemodialisis. Sebanyak 23 pasien, kemudian pasien dengan komorbid hipertensi sebanyak 21 orang dan pasien dengan komorbid penyakit jantung sebanyak 5 orang. Sari, dkk (2019), menemukan diabetes sebagai faktor resiko murni mempengaruhi luaran kegagalan AVF, sedangkan hipertensi berdasarkan analisis 
bivariate memiliki hubungan bermakna dengan kegagalan AVF. Yan Y., et al., (2018), dalam sebuah meta analisisnya didapatkan pasien dengan diabetes berhubungan dengan kegagalan AVF pada hemodialisis.

Pasien gagal ginjal kronis yang menjalani hemodialisis harus menggunakan akses vaskuler. Pada penelitian ini dari 33 pasien dikelompokkan yang telah menjalani operasi AVF berdasarkan lokasi operasinya, yaitu radiocephalica dan brachiocephalica. Dari total 33 orang sampel, didapatkan 20 orang $(60,6 \%)$ pasien dengan prosedur radiocephalica dan 13 orang pasien $(39,4 \%)$ dengan prosedur brachiocephalica. Sari NM, et al (2019), menemukan lokasi AVF tidak memiliki hubungan yang signifikan dengan kegagalan AVF.

Pada penelitian ini tedapat 33 orang pasien yang telah menjalani operasi AVF, kemudian diambil data rekam medis hasil laboratorim pre op. peneliti hanya mengambil data labor nilai trombosit dan nilai hematokrit dimana kedua variable ini secara teori memiliki pengaruh dalam kegagalan AVF. Berdasarkan hasil data analisis disimpukan tingkat keberhasilan hemodialisis setelah AVF pertama yaitu dengan nilai trombosit antar 150.000-400.000 sebanyak 15 orang $(62,5 \%)$. Namun juga tingkat kegagalan AVF paling tinggi didapatkan pada nilai trombosit $150.000-400.000$, yaitu 9 orang $(37,5 \%)$, diurutan kedua pasien yang gagal AVF dengan nilai trombosit $>400.000$, sebanyak 5 orang $(62,5 \%)$. Kemudian data ini diolah dengan fisher test didapatkan nilai $p$-value $=0,323$ disini tidak terdapat hubungan antara nilai trombosit dengan kegagalan AVF. Disini peneliti menemukan nilai trombosit tidak berhubungan dengan kejadian kegagalan AVF, mungkin hal ini bisa jadi disebabkan karena banyaknya faktor-faktor lai yang bisa mempengaruhi nilai trombosit itu sendiri dan menyebabkan kegagalan AVF. Chang CJ, et al. (2005), telah melakukan penelitian dengan menilai aktivitas inflamasi sebagai thrombosis sebagai penyebab dominan terjadinya kegagalan AVF pada hemodialisis. Oleh karena itu bisa disimpulkan nilai trombosit tinggi bisa menyebabkan lambatnya aliran darah dan bisa merangsang faktor-faktor koagulan terbentuk sehingga bisa membentuk penyempitan (stenosis) atau trombus pada bagian anastomose AVF.

Fungsi trombosit dapat dinilai dengan menghitung kadar volume trombosit rerata atau mean platelet volume (MPV), sehingga MPV merupakan penanda aktivitas trombosit. Pada trombositopenia perifer akut, MPV meningkat akibat produksi trombosit muda yang berhubungan dengan aktivasi megakariosit. Sedangkan pada trombositopenia kronis, MPV yang lebih tinggi berhubungan dengan adanya trombopati (Lano, et al., 2019).

Sarioglu, et al (2019) dalam penelitiannya menemukan tingginya level rasio trombositlimfosit bisa menjadi faktor pendukung terbentuknya stenosis dan thrombosis pada pasien gagal AVF. Mereka menemukan nilai rata-rata trombosit yang menyebabkan thrombosis pada pasien gagal AVF adalah $249.37 \pm 84.74(1 \times 103 / \mu \mathrm{L})$. Dari beberapa hasil penelitian diatas, peneliti menyimpulkan bahwa point utama terjadinya kegagalan AVF dengan nilai trombosit bahwa bukan dari "nilai trombosit" itu sendiri yang menyebabkan kegagalan AVF, akan tetapi karena adanya komorbid seperti diabetes mellitus yang bisa menyebabkan inflamasi kronis dan menggangu dari elastisitas endotel, kemudian nilai trombosit yang tidak normal atau tinggi hal ini menyebabkan terjadinya thrombus pada anastomose AVF sehingga bisa terjadi sumbatan atau stenosis pada AVF dan menyebabkan aliran AVF terganggu, sehingga pasien tidak bisa menggunakan AVFnya (Sarioglu, et al., 2019).

Penelitian lain yang dilakukan Lano, et al. (2019) menunjukkan bahwa kejadian disfungsi akses vaskular lebih tinggi pada pasien dengan MPV tertinggi ( $p$-value $=0.001)$ dimana resiko kejadian kegagalan akses vaskular 3 kali lebih tinggi pada pasien dengan MPV yang tinggi dibandingkan dengan pasien MPV yang rendah. Sehingga, peneliti menyebutkan bahwa MPV dapat dijadikan biomarker disfungsi akses vaskular dan membantu klinis dalam mengidentifikasi populasi beresiko tinggi. Penelitian lain mengevaluasi rasio MPV/trombosit sebagai prediktor patensi akses vaskular pada pasien yang menjalani hemodialisis. Hasil penelitian didapatkan bahwa rasio MPV/hitung trombosit secara signifikan meningkat pada pasien dengan kegagalan akses vaskular dibandingkan pasien tanpa kegagalan askes vaskular ( $p$-value $<0.001)$.

Selanjutnya dari penelitian ini, nilai hematokrit didapatkan hubungan yang bermakna dengan kegagalan AVF pada pasien hemodialisis dengan nilai $p$-value $=0,003$ secara statistik bermakna nilai. Sebanyak 19 orang $(70,4 \%)$ dengan nilai hematokrit $<33 \%$ berhasil hemodialisis pada AVF pertama dan tingkat kegagalan terendah terdapat pada nilai trombosit 33-36\% sebanyak 2 orang.

Pasien dengan kadar hematokrit tinggi berhubungan dengan trombosis, dan pasien dengan polisitemia vera atau atau mendapatkan 
eritropoietin lebih rentan terhadap trombosis dan trombosembolisme. Hematokrit yang tinggi meningkatkan kadar viskositas darah yang mengganggu aliran darah. Efek hematoreologi eritrosit ini merupakan faktor protrombotik yang kuat karena gangguan aliran darah merupakan komponen triad Virchow yang menjelaskan mekanisme patofisiologi trombosis diantaranya hiperkoaguabilitas, gangguan aliran darah dan kerusakan endotel. Viskositas darah yang berhubungan hematokrit memiliki efek fisik terhadap interaksi antara trombosit dan permukaan pembuluh darah. Pada aliran darah, adhesi trombosit meningkat seiring dengan pertambahan hematokrit. Sehingga, fraksi volume eritrosit memiliki pengaruh terhadap hemostasis dan thrombosis (Lano, et al., 2019)).

Peneliti menyimpulkan pada pasien dengan kadar hematokrit tinggi berperan penting terjadinya hiperkoagulasi dalam darah dan ini memicu terjadinya thrombus dan gagal AVF, karena pada penelitian ini terdapat bahwa nilai hematokrit $>36 \%$ angka kegagalan 4 orang (100\%) pada AVF pertama pasien GGk yang akan dihemodialisa dan secara statistik signifikan dengan $p$-value $=0,003$ (Lano, et al., 2019).

\section{DAFTAR PUSTAKA}

Chang, C. J., Ko, Y. S., Ko, P. J., Hsu, L. A., Chen, C. F., Yang, C. W., ... \& Pang, J. H. S. (2005). Thrombosed arteriovenous fistula for hemodialysis access is characterized by a marked inflammatory activity. Kidney international, 68(3), 1312-1319.

Galley, H. F., \& Webster, N. R. (2004). Physiology of the endothelium. British journal of anaesthesia, 93(1), 105-113.

Gołębiowski, T., Weyde, W., Kusztal, M., Porażko, T., Augustyniak-Bartosik, H., Madziarska, K., ... \& Klinger, M. (2015). Vascular access in diabetic patients. Are these patients "difficult"?. Advances in Hygiene \& Experimental Medicine/Postepy Higieny $i$ Medycyny Doswiadczalnej, 69.

Kaygin, M. A., Halici, U., Aydin, A., Dag, O., Binici, D. N., Limandal, H. K., ... \& Savur, A. I. (2013). The relationship between arteriovenous fistula success and inflammation. Renal failure, 35(8), 10851088.

Lano, G., Sallée, M., Pelletier, M., Bataille, S., Fraisse, M., Berda-Haddad, Y., ... \&
Saat ini, belum terdapat konsensus global mengenai target hematokrit (Ht) optimum pada populasi pasien ini. Namun, rentang normal nilai $\mathrm{Ht}$ adalah $37-48 \%$ untuk perempuan dan $42-52 \%$ untuk laki-laki (NKDEP, 2014). Pedoman yang sudah ada mengajukan Hemoglobin $(\mathrm{Hb})$ target $>11 \mathrm{gr} / \mathrm{dl}$ dengan nilai rerata $12-12,5 \mathrm{gr} / \mathrm{dl}$ (European Best Practice Guidelines) dan Ht 3336\% (Hb 11-12 g/dl; NKF-DOQI Guidelines). Sarioglu, et al. (2019) menemukan nilai hematokrit trata-rata terjadinya thrombosis pada pasien gagal AVF $35.02 \pm 6.15 \%$ walaupun secarat statistik tidak bermakna dengan $p$ value $=0,699$.

\section{SIMPULAN}

Dari data karakteriktik responden didapatkan usia 45-60 tahun dan jenis kelamin laki-laki merupakan pasien terbanyak menderita GGK. Terdapat hubungan nilai hematokrit preop dengan kegagalan AVF pada hemodialisis pertama pada pasien gagal ginjal kronis.Tidak terdapat hubungan antara nilai trombosit pre op dengan kegagalan AVF pada pasien hemodialisis pertama kali pada pasien gagal ginjal kronis.

Burtey, S. (2019). Mean Platelet Volume Predicts Vascular Access Events in Hemodialysis Patients. Journal of clinical medicine, 8(5), 608.

MacRae, J. M., Ahmed, S., Hemmelgarn, B., Sun, Y., Martin, B. J., Roifman, I., \& Anderson, T. (2015). Role of vascular function in predicting arteriovenous fistula outcomes: an observational pilot study. Canadian Journal of Kidney Health and Disease, 2(1), 19.

Martinez-Mier, G., Camargo-Diaz, C., UrbinaVelazquez, M. A., \& Avila-Pardo, S. F. (2020). Predictive Factors for Unsuccessful Use of Arteriovenous Fistula in a Population of End-Stage Renal Disease Patients in Southeastern Mexico. Annals of Vascular Surgery, 62, 304-309.

NKDEP. (2014). Vascular Access for Hemodialysis. Natl Kidney Dis Educ Progr. United States

Parisotto, M. T., Schoder, V. U., Miriunis, C., Grassmann, A. H., Scatizzi, L. P., Kaufmann, P., ... \& Marcelli, D. (2014). Cannulation technique influences 
arteriovenous fistula and graft survival. Kidney international, 86(4), 790797.

Pearson, J. D. (1994). Vessel wall interactions regulating thrombosis. British medical bulletin, 50(4), 776-788.

Santoro, D., Benedetto, F., Mondello, P., Pipitò, N., Barillà, D., Spinelli, F., ... \& Buemi, M. (2014). Vascular access for hemodialysis: current perspectives. International journal of nephrology and renovascular disease, 7 , 281.

Schinstock, C. A., Albright, R. C., Williams, A. W., Dillon, J. J., Bergstralh, E. J., Jenson, B. M., ... \& Nath, K. A. (2011). Outcomes of arteriovenous fistula creation after the Fistula First Initiative. Clinical Journal of the American Society of Nephrology, 6(8), 1996-2002.
Sari, N. M., Semadi, I. N., \& Widiana, I. G. R. (2019). Faktor-faktor risiko yang berperan terhadap terjadinya kegagalan arteriovenous fistula pada pasien gagal ginjal kronis stadium akhir di RSUP Sanglah. MEDICINA, 50(1), 20-26.

Sarioglu, O., Capar, A. E., \& Belet, U. (2019). Relationship of arteriovenous fistula stenosis and thrombosis with the plateletlymphocyte ratio in hemodialysis patients. The Journal of Vascular Access, 1129729819894113.

United States Renal Data System. (2015). 2015 USRDS annual data report, volume 2: ESRD in the United States.

Yan, Y., Ye, D., Yang, L., Ye, W., Zhan, D., Zhang, L., ... \& Chen, Q. (2018). A metaanalysis of the association between diabetic patients and AVF failure in dialysis. Renal failure, 40(1), 379-383. 